\title{
10101 オープンイノベーション (3)
}

創 薬

シリーズ(7)

\section{創薬オープンイノベーションセンター}

創薬シーズの創製に向けた研究支援ネットワークー

\section{小島 宏建, 岡部 隆義, 長野 哲雄}

要約：我が国の低分子創薬の研究分野においては, ア カデミアからオープンイノベーションを進める基盤が なく，偶然の発見や天然物の難しいスクリーニングか ら得られた数限られた創薬シーズを企業に橋渡しする しか手段がなかった。私たちはこの障壁を取り払うべ く, 化合物ライブラリー, スクリーニング設備, 合成 展開チームを整備し，創薬研究に挑戦できるスタート 台に誰でも立てるように漸くできた. アカデミアに埋 もれた創薬アイデアから企業が興味を持つレベルの創 薬シーズへと磨き上げる本研究支援プロジェクトを加 速させたく, 今後とも各方面からのご協力をお願いし たい.

\section{1.はじめに}

大学等アカデミアにおいても基礎研究成果の応用, 実用化が重視される時代になり，「産学連携」がキーワ ードとなって久しい. 近年, 新たなキーワードとして 「オープンイノベーション」が取り上げられることが 多くなっているが, 実のところ, アカデミアにおいて は共同研究, 産学連携とほとんど同義であり, 以前か ら行われている取り組みである。オープンイノベーシ ヨンとは主に企業において, 自社研究開発のみで製品 開発を進めるのではなく, 自社以外の知識や技術を取 り入れて新たなテーマ創出や開発の効率化を進めるこ とである. 製薬企業においても, 製品化合物の特許切 れや創薬標的の涸渇などの問題から広く創薬テーマを 公募し, 研究の進め方について協議しながら, 必要な 研究経費を供与する取り組みが増えている. 最近, 海 外も含め, 数社がこのような公募を行っていることか ら，他社に優良テーマを青田買いされることを警戒し てか, 具体的な募集テーマの範囲を提示する公募の効
率化も行われるようになっている.

このように標的とするテーマ等, 従来は手の内を明 かすことのなかった企業側からの橋渡しが進められて いる一方, アカデミアにおいても, 前臨床から臨床研 究レベルのトランスレーショナルリサーチの支援が大 学病院等ですでに進められてきている。私たちもさら に上流の基礎研究から創薬シーズ創製までを支援する 全国規模のネットワークを構築してきた. 元々製薬企 業への創薬シーズの提案はアカデミアからも頻繁に行 われていたと思われるが, 再現性に欠けるチャンピオ ンデータの提示に留まるなどとして, ほとんどが丁重 な門前払いを受ける提案だったと伺うことが多い.そ れは企業が望むレベルの創薬研究の土䁃がアカデミア にはなかったことに起因する。私たちは，このような 状況にあった創薬研究をボトムアップするために研究 支援ネットワークを構築した．本プロジェクトについ て以下に紹介したい.

\section{2. アカデミアには創薬シーズが溢れんばかり？}

$\lceil\bigcirc ○$ 大学で $\times \times$ 解明！ 新薬開発に繋がる大発 見！！」といった新聞報道が毎日のようになされてい る.ならば, アカデミアで行われた基礎研究で得られ た創薬シーズから臨床研究への橋渡し研究が, さぞや 盛んに行われているのであろう。しかし, 低分子医薬 品創製研究における実態はそれとは全くかけ離れたも のである.なぜであろうか？

解明された $\times \times$ を制御する低分子を見出すためには 探索研究（化合物スクリーニング）が必要になる。化 合物スクリーニングは製薬企業で日常的に行われてい るが，新聞報道される標的がヒトの疾病治療に関わっ ていることが全く明確になっていない段階で, スクリ

キーワード：スクリーニング, 化合物ライブラリー, オープンイノベーション, 公的支援, 創薬 東京大学 創薬オープンイノベーションセンター（テ113-0033 東京都文京区本郷 7-3-1 薬学部本館） 原稿受領日：2013 年 2 月 26 日, 依頼原稿

Title: Open innovation center for drug discovery: a research-supporting network for drug-seeds discovery Author: Hirotatsu Kojima, Takayoshi Okabe, Tetsuo Nagano 
ーニングが開始されることはない。一方において，大 発見した○○大学の研究グループは化合物スクリーニ ングを自ら行って， ××を制御する化合物を見出す研 究を行う手段は全くなかった。そのため, 当然ながら 基礎研究で発見された生物活性を有する低分子化合物 が我が国で橋渡しされることは, 極めて稀なケースと なっていた。

であるからと言って，その発見を学会や論文での発 表でそのままにしてしまい，誰もリスクを取らなけれ ば，創薬テーマが涸渇するのは当たり前である，そこ で，私たちは以下に述べるように，アカデミアにおい て創薬研究の基盤が整備されていない現状を一つ一つ 解決すべく，スクリーニングのために誰もが利用でき る大規模な公的化合物ライブラリーを整えた。最先端 の基礎研究の成果に由来する創薬アイデアから, 企業 が興味をもつレベルの創薬シーズに磨き上げることを 目指してきている.

\section{3. 基盤と体制の整備}

私たちが本プロジェクトに着手した 2006 年以前か ら, 海外においてはスクリーニング用の化合物ライブ ラリーがアカデミアにおいても整えられていた，特に 米国においては個々の大学で保有されていることも珍 しくない，我が国においては，職人技とも言える天然 物スクリーニングや偶然の発見などに頼らざるをえな い状態で, 誰もが創薬研究に着手することはできなか った。

そのような状況下, 文部科学省事業「ターゲットタ ンパク研究プログラム」において, タンパク質機能の 制御化合物の発見に有用な基盤として, 公的な大規模
化合物ライブラリーを整備することに私たちは取り組 んだ．創薬研究は様々な知識を集約して行う必要があ り, 個人研究としては決して完遂できない。この事業 では生物学, 生化学, 医学, 構造生物学, 有機化学, 情 報学等異分野の研究者が一つのチームを組んだ。標的 タンパク質の制御化合物を探索するという従来にはな い体制で推進され, 数々の興味深い化合物の発見に繋 がっている. 研究者が同じ目標を目指し, タンパク質 と化合物を中心に置いて対等に議論する土壤が拓かれ た意義のある事業であった。同事業で築かれた化合物 ライブラリーは 21 万サンプルを所蔵するに至ってお り（図 1), 文部科学省創薬等支援技術基盤プラットフ オーム事業で引き続き運営され, 利用を希望する研究 者に産・学・官の区別なく公開されている.

化合物ライブラリーの詳細は東京大学創薬オープン イノベーションセンターのホームページ(1) をご覧い ただきたいが，なるべく多くの標的に活性化合物が見 出されるよう分子構造の多様性を考慮して収集されて いる。 そのような汎用ライブラリ（General Library） の他にもキナーゼ (kinase) や GPCR, タンパク質間 相互作用など特定の標的を阻害する確率が汎用ライブ ラリより高いと予測した候補化合物のセットであるフ オーカストライブラリ (Focused Library)，あるいは， 既知薬理活性化合物が取り揃えられている。既知薬理 活性化合物は，構築したアッセイ系の評価や制御した い生体標的の探索, あるいは既知活性以外の薬理活性 の発見を目指す研究テーマで用いられる. 申請書を受 理すると，そのライブラリーより化合物サンプルの 2 $\mathrm{mM}$ または $10 \mathrm{mM}$ のジメチルスルホキシド (DMSO) 溶液を 96 穴や 384 穴のマイクロプレートに分注して,

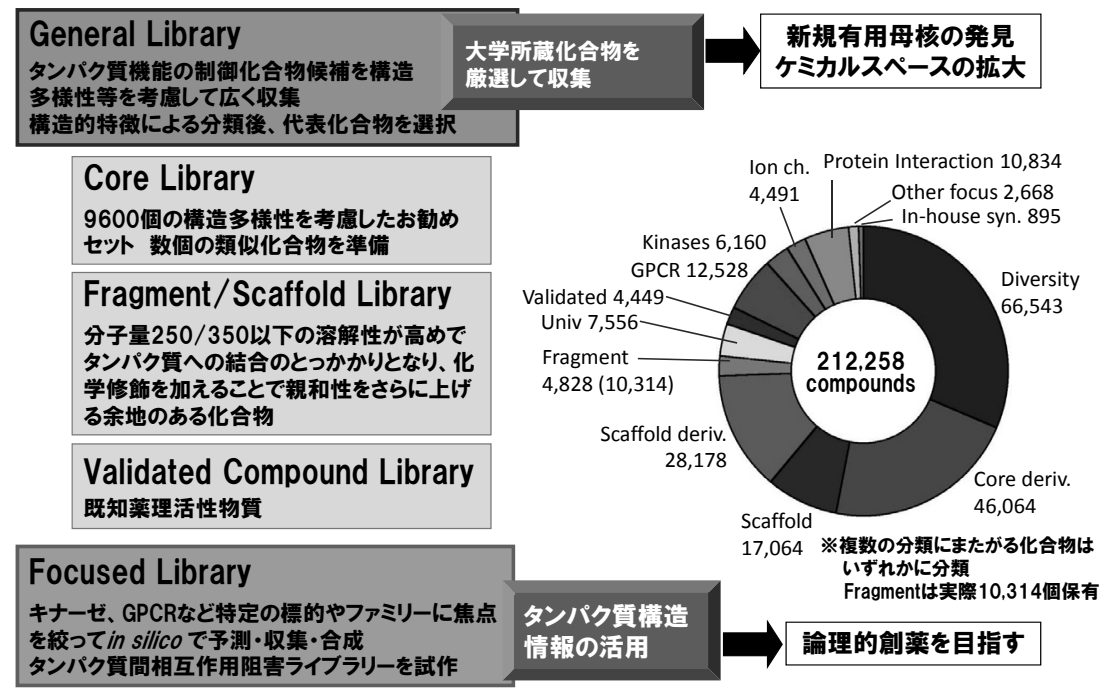

図 1 東京大学の化合物ライブラリーの構成（2013 年 3 月） 
冷凍便にて発送している（図 2)。化合物サンプル自体 は無償で，提供に要する消耗品や送料等の実費負担の みで利用可能である.

このように誰でも化合物サンプルにアクセスできる 体制が整ったが，アカデミアではマイクロプレートに 入った化合物サンプルを取り扱う装置類はこれまで必 要とされず，全くと言ってよいほど備わっていなかっ た，そこで，文部科学省の補助を得て，東京大学以外 にも北海道, 東北, 京都, 大阪, 九州, 長崎の各大学
に自動分注装置やスクリーニング装置を設置し，全国 規模でのスクリーニング研究支援体制を整えることが できた。これらの装置を外部利用者にも開放する（図 3）だけでなく，化合物スクリーニングが初めてである ほとんどの利用者に，スクリーニング講習会を催すな どソフト面での支援内容も充実させている.

各センターでの研究支援は, アイデアやテーマ持込 に対応したスクリーニング請負というよりは，手厚い 支援を受けながらも申請者のグループ自身が主体とし

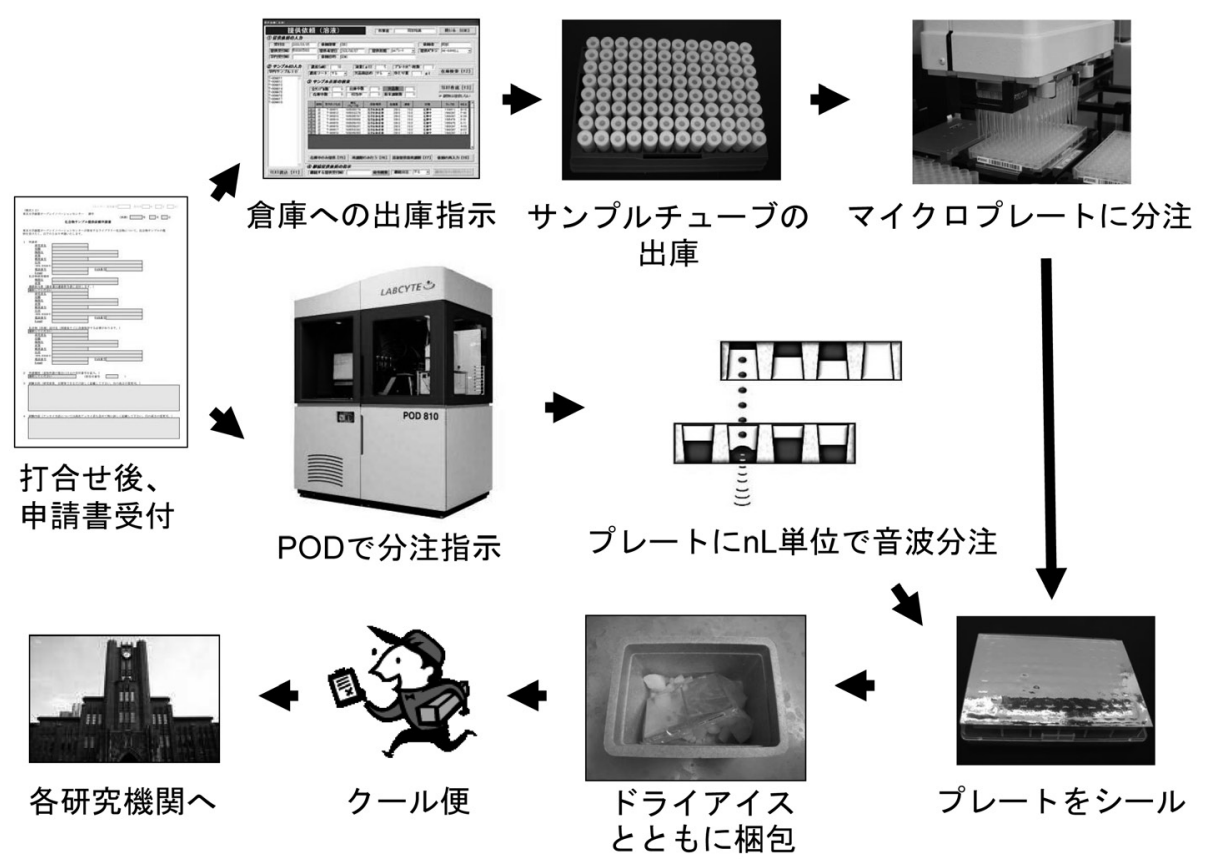

図 2 化合物サンプルの送付方法

96 穴や 384 穴のマイクロプレートに化合物サンプルの溶液を分注して冷凍便で届けている. Plate on Demand (POD) 装置により, $5 \mathrm{~nL}$ 刻 みでの分注も可能となり，届いたプレートを中間希䣋せず, プレートヘダイレクトに試験液を加えて測定できるアッセイレディプレートの提供 も開始している.
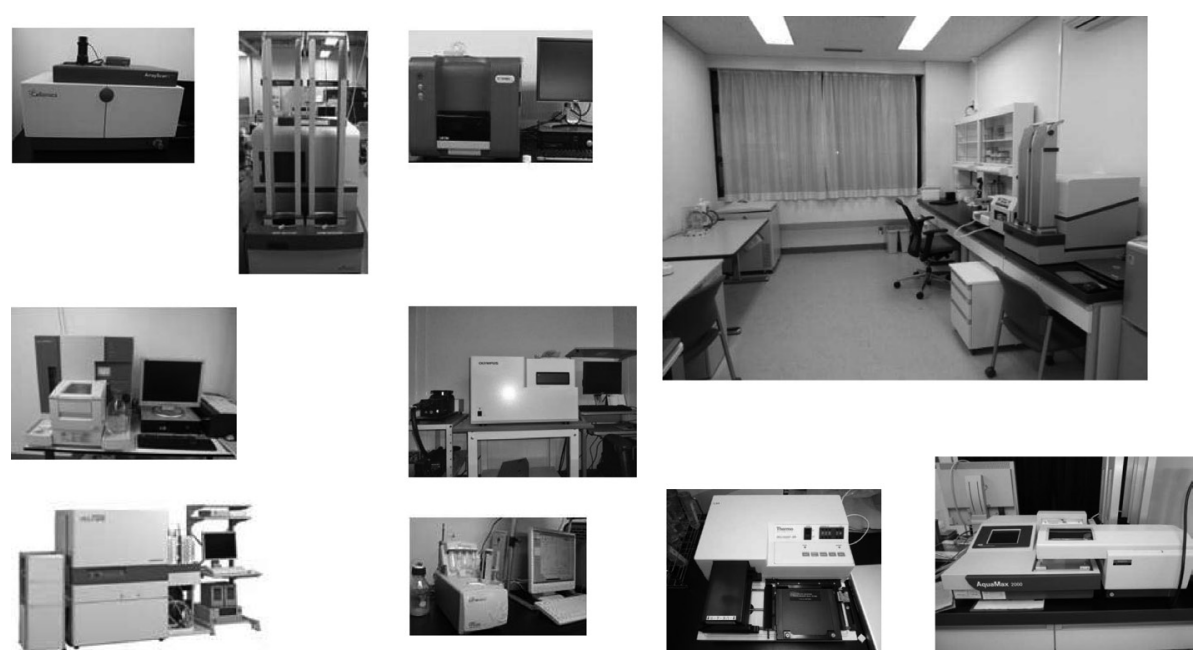

図 3 スクリーニング機器の利用開放

北海道, 東北, 東京, 京都, 大阪, 九州, 長崎の各大学の創薬拠点では, スクリーニングに必要な機器をご利用いただくこともご相談により可能. 
て進めることを基本にしている．スクリーニングに慣 れたスタッフが請負って行う方が効率的ではあるが, 請負えるキャパシティには限りがあるため，採択する テーマを厳しく選定する必要があり, アカデミア研究 の長所である自由で豊かな発想からの発見が阻害され る䀣念がある.ささらに，そのテーマに対して最も熱意 のある研究者自身が中心となって推進する方が，成功 の鍵を粘り強く探索できる。「創薬」という語を造ら れた野口照久先生が残された

新たなる創造は 夢で作られ 情熱で究められ 使命感で結晶する

というお言葉がまさにそのことを物語っているよう に思う.

表 1 に示したのは最近までの東京大学創薬オープン イノベーションセンターの支援実績である. 全国複数 の拠点のスクリーニング設備にアクセスできるように なったことから，相談件数が飛躍的に増えてきている. これらの支援内容は企業にも開放されているが, 研究
テーマの開示を躊躇したり, 知的財産権の取り扱いを 懸念して利用を見送るケースが多いように思う。とは いえ, 別の企業への提供実績を見て, 情報漏洩等の懸 念が払拭されたためか, 提供件数が最近は着実に増加 している.

化合物サンプル提供前には, 提供する化合物サンプ ルの種類や数, スクリーニング方法と活性化合物候補 （ヒット化合物）が見出された場合の見極め方法など, 細部に至るまで丁寧に打ち合わせを当センターにおい て必ず行っている (表 2). 当センターには製薬企業で のスクリーニング研究実績のあるエキスパートが複数 名在籍しており, アカデミア研究者に対しても厳しい 指摘を行っているが, 決して申請者をいじめるわけで はない。 より適切なアッセイ系や，スクリーニングを 実施した後に行き詰まることを回避するための対策を 提案するなど, 遠方から来られるアカデミアの研究者 も, 皆さん納得し, 満足して戻られる.

スクリーニング基盤が形成されると，次のステップ としてはスクリーニングヒット化合物から活性や物性 のさらに良い化合物を探索するための化学合成基盤が

表 1 平成 25 年 3 月現在までの東京大学における化合物提供支援実績

\begin{tabular}{|c|c|c|}
\hline & 問い合わせ研究者数 & $\begin{array}{l}\text { 化合物データベースや } \\
\text { サンプル提供者数 }\end{array}$ \\
\hline 国公立大学 & 174 & 113 \\
\hline 私立大学 & 17 & 10 \\
\hline 公的研究機関 & 61 & 46 \\
\hline 企業 & 34 & 9 \\
\hline 合計 & 286 & 178 \\
\hline \multicolumn{3}{|c|}{$\begin{array}{l}\text { 申請書件数ベースでは } 865 \text { 件受付（内部利用含） } \\
\text { サンプル数ベースでは } 583 \text { 万サンプル提供済（内部利用含） } \\
\text { 外部研究者との打合せ等 : } 818 \text { 回（週に } 2 \sim 3 \text { 回の頻度） }\end{array}$} \\
\hline
\end{tabular}

平成 19 年度から始まったターゲットタンパク研究プログラムで東京大学に化合 物ライブラリーを構築してサンプル提供支援を開始し, 平成 21 年からはサンプ ル提供支援を産学官の区別なく一般研究者にも開始した。 スクリーニング設備 の共用も行っており，学内外の研究者のべ 1000 名以上の利用実績がある.

表 2 打合せ時にご説明いただきたい内容

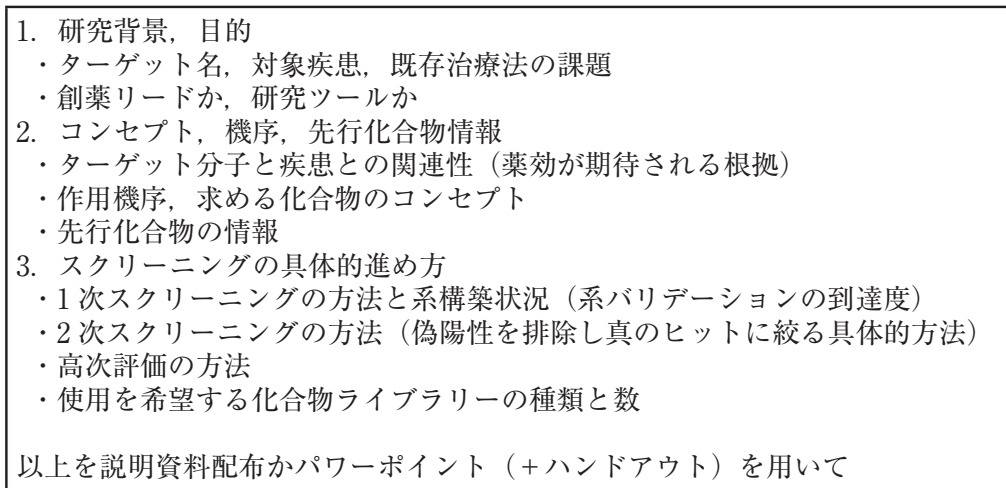




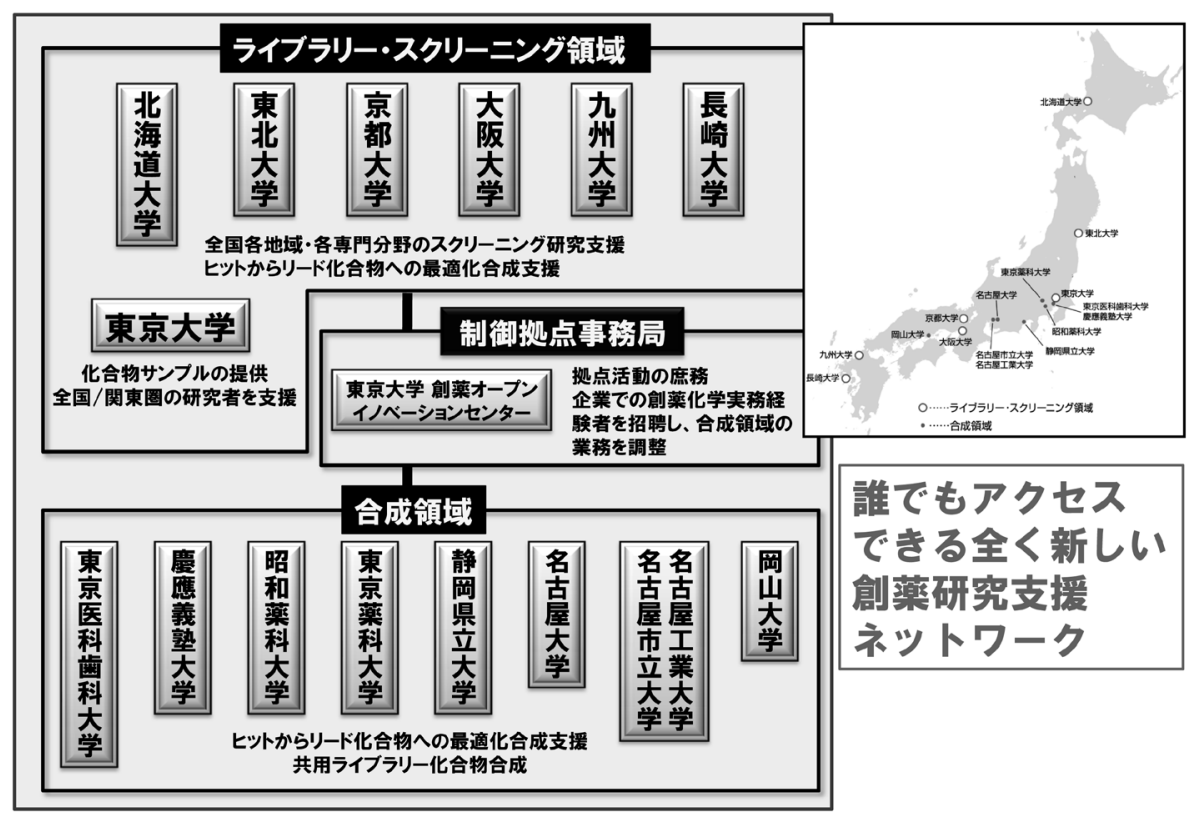

図 4 創薬等支援技術基盤プラットフォーム制御拠点

必要となる。そのため, 文部科学省創薬等支援技術基 盤プラットフォーム事業で，9大学からなる 8 チーム を選定していただいた。これらの大学はヒット化合物 からの最適化合成を支援すると共に，公的化合物ライ ブラリーの充実のためにユニークな化合物を提供して いる (図 4).

\section{4. アカデミア創薬の方針と問題点}

基礎研究を担うアカデミアと製品開発を行う企業の 双方から歩み寄り, オープンイノベーションを進める ことは, 間違いなく新しい創薬シーズの発見に不可欠 な取り組みであろう。開発が後回しにされてきた稀少 疾患や難治疾患の治療薬開発のハードル低下に繋がる であろうし，創薬コンセプトが確立していない研究テ ーマについては，企業が担う創薬リスクの低減を図る ことができる.アカデミアでのスクリーニングは具体 的な標的生体分子を定めずに行う，フェノタイプスク リーニングが非常に多い. 目標に到達するまでの手数 や時間がかかるであろうが，その中から一つでも，二 つでも画期的な医薬品開発に繋がることが期待できる と考えている.

現在, 政府が進める医療イノベーションの取り組み の一つして, 私たちが推進してきたような基礎研究か ら企業への橋渡し支援が検討されているようである。 どのような予算配分や取り組みを行うにせよ, 問題と なるのは支援を行う人材である。すなわちアカデミア において製薬企業等で行われるレベルの創薬探索研究 経験がなく, 当然ながら, 指導的人材が圧倒的に不足
している. 我が国の創薬分野においても，アカデミア と企業間の転職や出向を含む人事交流が進むことが望 まれるが，そのためにはアカデミア側の受入体制や規 則（長期契約可能ポストやキャリアパス）の整備が必 要である. もちろん, 改正労働契約法, 雇用財源, 承 継教員ポストの削減といった様々な問題が関係し, 研 究分野の事情のみで進められるわけではないので, 各 方面を調整しつつ, 徐々に解決したい問題である. 元 来大学では教育を本務としており，これまでに全くな かったこのような取り組みや創薬関連設備に, 学生や 若手研究者が間近に触れることができることは，長期 視点での人材養成には確実に貢献できる.

一方，アカデミアにおける人事評価が公表論文に基 づくため, キャリアアップや学位取得には成果の公表 が必要で, 知的財産権確保や特許戦略とのコンフリク トが生じる。製薬企業が活用できる特許は単なるスク リーニングヒット化合物の用途特許ではない. 類縁化 合物を合成し, 活性比較等を行った上で, 確保が必要 な権利範囲をクレームした特許出願が必要となる。研 究開始からその特許が公開されるまでの期間は情報秘 匿されなければならず，見つかったシーズが良いほど， 関わった研究者のキャリアアップにはダメージとなる. 従って, ヒット化合物発見後の検討はできる限り迅速 に行いたいが，人材や資金等のリソースが充足してい ることはまずないので, 魅力的なテーマであれば, 出 願前に企業と共同研究に進め, 加速することも必要で あろう.アカデミアの研究現場では, 複数のテーマに 学生等がかかわことにより, 学位取得で不利になら 
ないような工夫をしたり, ヒット化合物のうち, 発表 用の化合物と創薬展開を模索する化合物をあらかじめ 分離するなど，様々な対策が事前に必要になろうかと 思う。

\section{5. おわりに}

これまで本プロジェクトに携わってきて，お願いし たいことの一つが短期の評価ではなく, 中長期的な視 点での評価である。貴重な税金を用いた事業なので効 率性や経済性のチェックが必要で, 致し方ない面もあ るが, 創薬研究の土壤がほとんどなかったところから スタートしているため, 体制整備や人材育成にそれな りの時間を要し, さらに創薬研究自体, 数年以上の年 月を必要とすることをご理解いただきたい．また，企 業での経験者の参画がもっと増えれば，シーズ発掘の スピードが加速するものと思う，皆さまのご協力を東
心よりお願いする次第である.

\section{参 考 情 報}

1) http://www.ocdd.u-tokyo.ac.jp/
著者プロフィール

小島 宏建（こじま ひろたつ）

東京大学創薬オープンイノベーションセンター, 副センター 長・特任教授. 博士 (薬学).

$\diamond 1995$ 年東京大学薬学部薬学科卒業, $\nabla 00$ 年東京大学大学院薬 学系研究科博士課程修了, $\bigotimes 00$ 年 $\bigotimes 02$ 年米国カリフォルニア大 学サンデイエゴ校博士研究員, $\bigotimes 02$ 年東京大学大学院薬学系研究 科助手, $\bigotimes 07$ 年東京大学生物機能制御化合物ライブラリー機構特 任准教授, $\bigotimes 12$ 年より現職. 